\title{
Petrography and Geochemistry of the Mbip Granitic Massif, SW Tcholliré (Central North Cameroon): Petrogenetic and Geodynamic Implication
}

\author{
Emmanuel Nomo Negue ${ }^{1,2 *}$, Rigobert Tchameni ${ }^{2}$, Olivier Vanderhaeghe ${ }^{3,6}$, \\ Pierre Barbey ${ }^{4,5}$, Periclex Martial Fosso Tchunte ${ }^{2}$, Jonas Didero Takodjou Wambo', \\ Brice Yanick Lemdjou', Nicaise Alliance Saha Fouotsa ${ }^{2}$

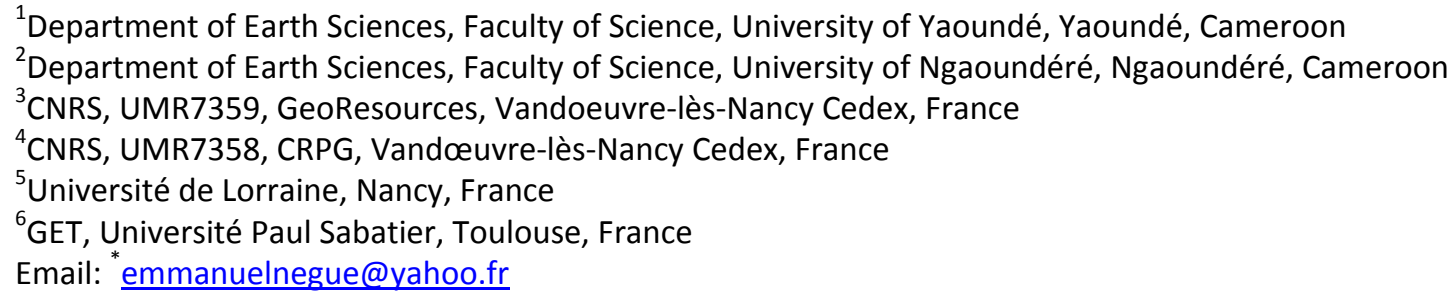

Received 17 June 2015; accepted 25 July 2015; published 30 July 2015

Copyright (C 2015 by authors and Scientific Research Publishing Inc.

This work is licensed under the Creative Commons Attribution International License (CC BY).

http://creativecommons.org/licenses/by/4.0/

(c) (i) Open Access

\section{Abstract}

In this article, we discussed about the petrography and geochemistry of magmatic rocks of the Mbip massif located SW of Tcholliré, in Central North Cameroon (Central African Fold Belt). Petrographic study shows that this massif is made of granodiorite, amphibole-biotite granite, and biotite granite which often contain enclave of mafic rocks (gabbro). Granodiorites and granites show porphyritic texture and consist dominantly of plagioclase and alkaline feldspar phenocrysts, quartz, biotite and often few amphibole. The gabbro enclaves are characterized by a granular porphyroid texture constituted of amphibole, plagioclase and olivine phenocrysts, all in a matrix of small crystals of plagioclase, olivine, amphibole, pyroxene and opaque minerals. All the analyzed rocks provide geochemical features of sublkaline serie and have nothing to do with the alkaline nature previously signaled in the former works. Granodiorites and granites are shoshonitic to calc-alkaline strongly potassic affinity consistent with emplacement in the continental collision setting. They present positive anomalies in $\mathrm{Rb}$, Th, $\mathrm{U}$; negative anomalies in $\mathrm{Sr}, \mathrm{P}, \mathrm{Ti}, \mathrm{Nb}$, Ta and some facies contain hydrated minerals such as amphibole. These characters are consistent with crustal and mantle contribution in their genesis. The mafic rocks (gabbro) have geochemical characteristics conferring a mantle origin, as confirmed by the high Mg\# value (49.9). On the whole, the fractional crystallization of the magma formed by melting of crustal material and the magmat-

${ }^{*}$ Corresponding author.

How to cite this paper: Negue, E.N., et al. (2015) Petrography and Geochemistry of the Mbip Granitic Massif, SW Tcholliré (Central North Cameroon): Petrogenetic and Geodynamic Implication. International Journal of Geosciences, 6, 761-775. 
ic mixing are the main petrogenetic process in the Mbip massif. Petrographic studies and geochemical data shows that the Mbip massif was emplaced in an active continental margin, into transitional regime from the end of maximum compression to the beginning of relaxation.

\section{Keywords}

\section{Central African Fold Belt, Granitic Rocks, Mafic Rocks, Transitional Regime, Active Margin.}

\section{Introduction}

The orogenic belt in Cameroon, studied in the Tcholliré region in north-central Cameroon, is part of the Central-African fold belt (CAFB, Figure 1, [1] [2]) and is still called North Equatorial fold Belt [3]-[6] or Oubanguides orogenic belt. The CAFB also spreads in Africa ontofrom Chad, Central African Republic and continues to the east of Sudan, Uganda and Tanzania [7]. In Cameroon this Belt has been divided into three lithological domains (Figure 1) separated by major late Pan-African transcurrent shear zones [2]. These fault zones from the south to the north are the Sanaga shear zone (SSZ), the Central Cameroon shear zone (CCSZ) and the Tcholliré-Banyo shear zone (TBSZ). Geological studies based on the structural analysis of different deformation phases show that this belt results from a collision among the Congo-São Francisco cratons, the West Africa craton and the Saharan and Latéa métacratons [8] [9].

In Cameroon, the Central African African Fold Belt is characterized by a wide distribution of granitoids of various ages and origins. These granitoids are classified into three groups and associated to different stages of orogenic evolution [1]. These are: 1) pre-tectonic granitoids that are calc-alkaline, associated to the pre-collisional evolution stage and emplaced between 660 and $670 \mathrm{Ma}$; 2) syn-tectonic granitoids that are calc-alkaline,

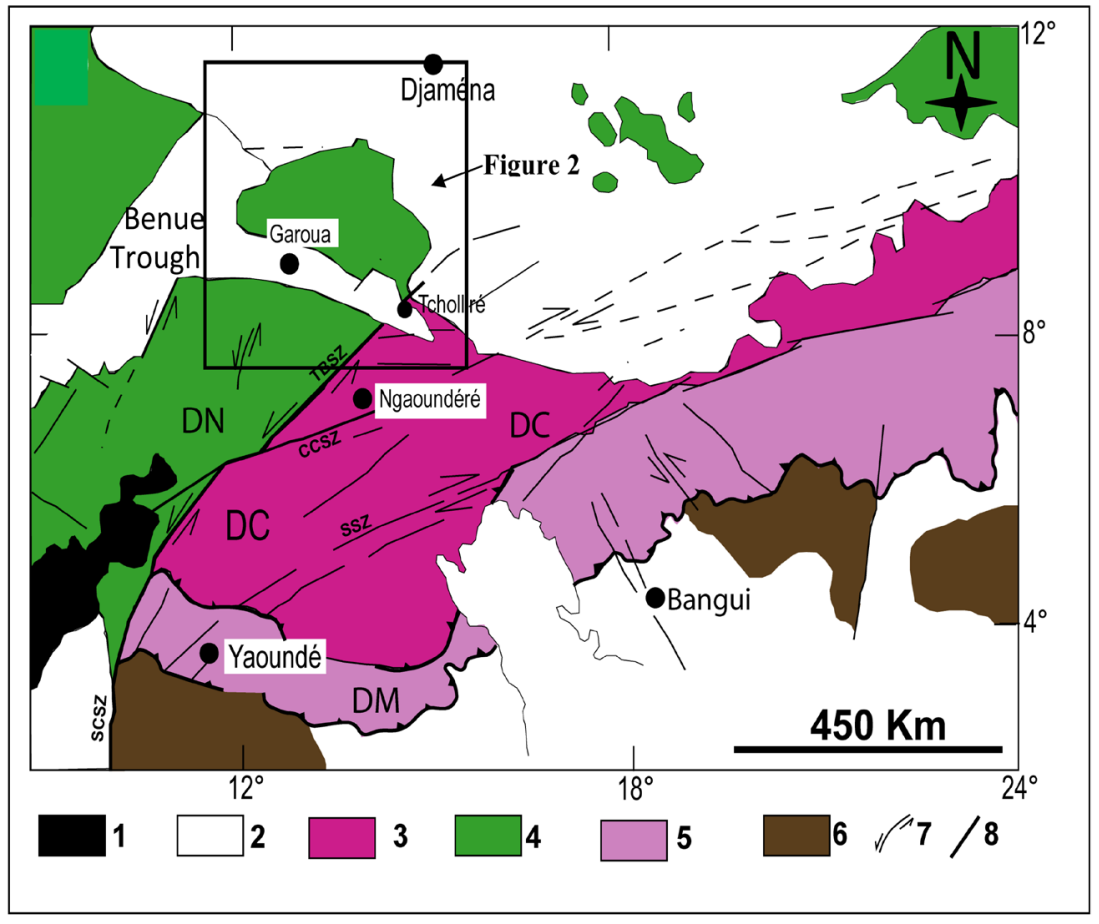

Figure 1. Geological map of the Central African Orogenic Belt. Redraw by Pinna et al., 1994 and Toteu et al., 2004. A: (1) Cénozoïc volcanic rocks of the Cameroon line; (2) Mésozoïc sediments; (3) Meridional Domain; (4) Central Domain; (5) Northern Domain; (6) Congo craton; (7) thrusting; (8) faults: TBZS, Tcholliré-Banyo shear zone; CCSZ, Central Cameroon shear zone; SSZ, Sanaga shear zone; SCSZ, South Cameroon shear zone. 
of S type, associated to the syn-collisional evolution stage and emplaced between 640 and $610 \mathrm{Ma}$; 3) late-tectonic granitoids that are calc-alkaline to sub-alkaline, linked to the post-collisional evolution stage and emplaced between 600 - 570 Ma.

Despite the numerous geological reconnaissance works have been operated in the study area, several PanAfrican plutons are still unstudied. This work focuses on the Mbip massif, which is located in the SW of Tcholliré area, near the Tcholliré Banyo Shear zone. Only geological reconnaissance studies have been conducted on this massif so far [10] [11], and therefore many gaps subsist in the knowledge of its petrography and geochemistry. Consequently, several questions concerning its petrogenesis and geotectonic environment remain unanswered. The aim of this work is to specify the nature and petrography of plutonic rocks constituting the Mbip massif in order to contribute to its mapping, its petrogenetic model and its tectonic setting. The results will allow expanding knowledge about the petrogenesis and geotectonic context of magmatism in north central Cameroon (Tcholliré region) in particular and the Central African Pan-African Fold belt in Cameroon in general.

\section{Geological Setting}

The studied massif is located at the south-west of Tcholliré city, in the south-east of the northern extension of the Tcholliré-Banyo shear zone that divides the Pan-African belt at the central north Cameroon into two distinct lithospheric domains (Figure 2), namely the Central or Adamawa-Yadé domain (DC) and the northern domain (DN).

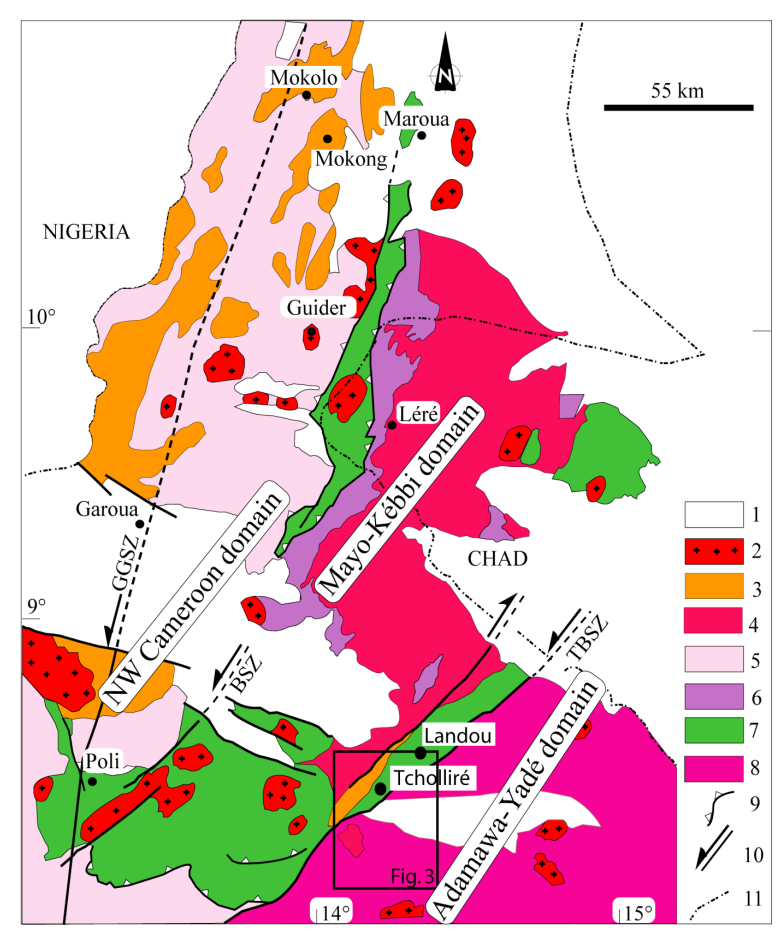

Figure 2. Geological sketch map of northern Cameroon (modified from Penaye et al., 2006): 1) Post-Pan-African sediments; 2) Late to post-tectonic Pan-African granitoids; 3) Syntectonic granite; 4) Mayo-Kebbi batholith: tonalite, trondhjemite and granodiorite; 5) medium- to high-grade gneisses of the Northern domain; 6) Mafic to intermediate complex of the Mayo-Kebbi domain (metadiorite and gabbro-diorite) and amphibolite; 7) Neoproterozoic low-tomedium-grade volcano-sedimentary sequences of the Poli-Léré Group; 8) Remobilized Palaeoproterozoic Adamawa-Yadé domain; 9) Thrust front; 10) Strike slip fault: TBSZ = Tcholliré-Banyo shear zone; GGSZ = Godé-Gormaya shear zone; 11) State border. 
The Adamawa-Yadé domain is composed of: 1) large remnant of Palaeoproterozoic orthogneiss and metasediments providing on one hand a significant contribution of an Archaean crust as shown by the presence of inherited zircon [2] [12], and on the other hand a Pan-Africain high pressure granulitic metamorphism dated at 600 Ma [13]; 2) a Neoproterozoic metavolcano-sedimentary package called Lom series, characterized by a Pan-African low to medium grade metamorphism [14] [15]; 3) slightly deformed granites (syn- to late-orogenic) of calc-alkaline to shoshonitic composition [16] [17], of crustal or mixed origin [1] [14] [18] [19] emplaced at around $600 \mathrm{Ma}$ [1] [20]. We note in this domain, several slip faults are like the Adamawa fault or Central Cameroon shear zone CCSZ [21].

The northern domain consists of medium to high-grade Neoproterozoic schists, metabasits and gneisses (Poli group) with a volcanic to volcano-sedimentary, origin developed in the range 850 - 665 Ma [15]. These rocks have been intruded by at least two generations of Pan-African granitic plutons: the oldest (660 - $585 \mathrm{Ma}$ ) includes pre-, to syntectonic calc-alkaline granites [1] [22]; while the youngest one (585 - $540 \mathrm{Ma}$ ) correspondd to the emplacement of late-tectonic granites.

Structurally, in both domains, the tectonic evolution comprises an early $\mathrm{D}_{1}$ deformation with a flat-layering S0-1 foliation. This phase has been attributed to the early Pan-African tectonic emplacement of nappes, verging toward the east [5] [23]. The second phase $\left(D_{2}\right)$ is characterized by the development of tight and upright folds with vertical axial plane schistosity $\mathrm{S}_{2}$.

\section{Methodology}

For the geochemical studies, six samples of granitic rocks and one gabbro were prepared. The size of samples were reduced and finely chipped at the GeoResources laboratory of "Université de Lorraine”, France. Sample chips were cleaned, crushed in an agate mortar, split by quartering and finely ground. Representative samples were analyzed by ICP-AES and ICP-MS at the Centre de Recherches Pétrographiques et Géochimiques of Nancy, France.

\section{Results}

\subsection{Geomorphology and Mapping}

The Mbip massif borders the Tcholliré massif in the SW (Figure 3(b)) and forms a zone of slightly elongated outcrop, about $7 \mathrm{~km}$ long and $4 \mathrm{~km}$ wide, oriented WNW-ESE approximately. In the previous regional geological maps [24]-[26], this relief is in form of circular pluton and the entire massif is often regarded as an alkaline granite [10] intruding the lower Proterozoic orthogneiss of Faro-Jibao [11]. On the field, the Mbip massif is mainly composed of granitic rocks sometimes containing sometimes mafic enclaves of gabbroic nature. Granites are the most abundant rocks, followed by granodiorites. Gabbros form elongated or angular enclaves and outcrops over large areas are scarce. Some granite and granodiorite outcrops (in the NNW extreme of the massif) are slightly structured. This structuring is well defined either by the orientation of feldspars and lengthening of mafic enclaves in granodiorites or by the orientation of biotite in fine-grain biotite granites. However, the rest of the massif (over $80 \%$ of its surface) is constituted of unstructured petrographic facies at the macroscopic scale (Figure 3(b)).

\subsection{Petrography}

\subsubsection{Mafic Rocks}

In the Mbip massif, the mafic rocks are represented by gabbros. They are dark coloured rocks often as enclave in granitic rocks of the Mbip Massif. These are rocks with massive structure, with granular porphyroid texture (Figure 4(a) and Figure 4(b)) constituted of amphibole, plagioclase and olivine phenocrysts, all in a matrix of small crystals of plagioclase, olivine, amphibole, pyroxene and opaque minerals. Secondary minerals are represented by calcite, epidote and chlorite.

Olivine is usually sub-automorphic to xenomorphic of varying sizes (200 - $600 \mu \mathrm{m})$. Some sub-rounded tracks are frequently altered. Plagioclase occurs as anhedral to sub-euhedral crystals $(\leq 400 \mu \mathrm{m})$ partially or completely altered in a mixture of sericite, epidote and chlorite. Amphibole is a brown hornblende. It occurs as euhedral crystals of varying sizes $(100-1200 \mu \mathrm{m})$. Some fringes indicate the development of chlorite and opaque minerals. Pyroxene appears as anhedral small crystals of varying sizes (200 - $400 \mu \mathrm{m})$. It often develops on 


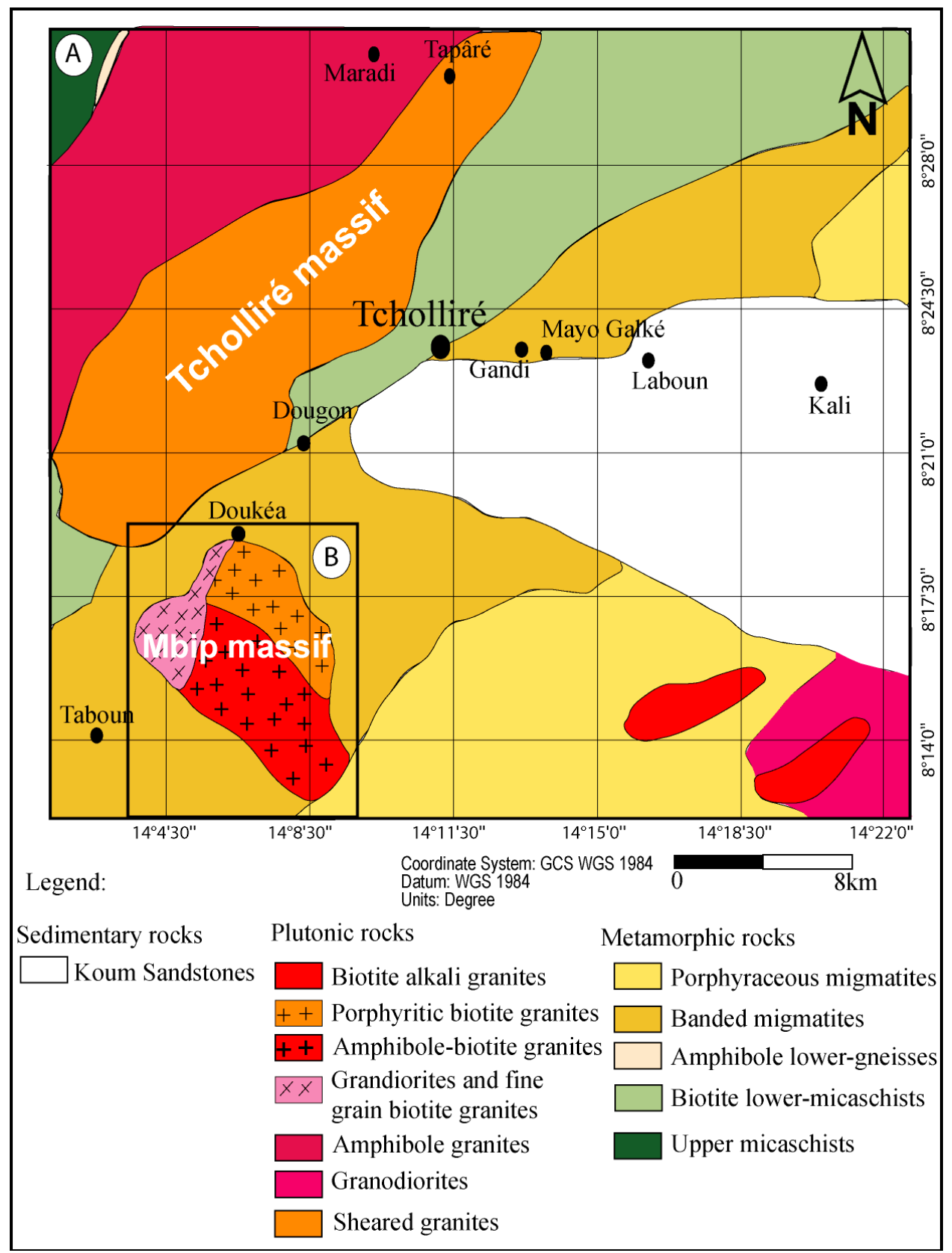

Figure 3. Geological map of the Tcholliré area (a) showing the main petrographic types of the Mbip massif (b). Modified after the geological recognition map of Cameroon (Garoua-Est) Leroy and Cirrotteau, (1962).

plagioclase. Calcite appears as sub-rounded crystals of varying diameter (600 - $1000 \mu \mathrm{m})$ and contains inclusions of opaque minerals, euhedral amphibole, pyroxene and olivine. Accessories minerals include opaque minerals.

\subsubsection{Granitic Rocks}

1) Granodiorites

Granodiorites outcrop in blocks at low and high altitudes of the Mbip massif. They have a light gray appearance and present quartz-feldspar veins in places. They also contain many micro-granular gabbroic enclaves (Figure 4(c)). These enclaves are melanocratic, angular or fusiform highlighting the rock formation process. 

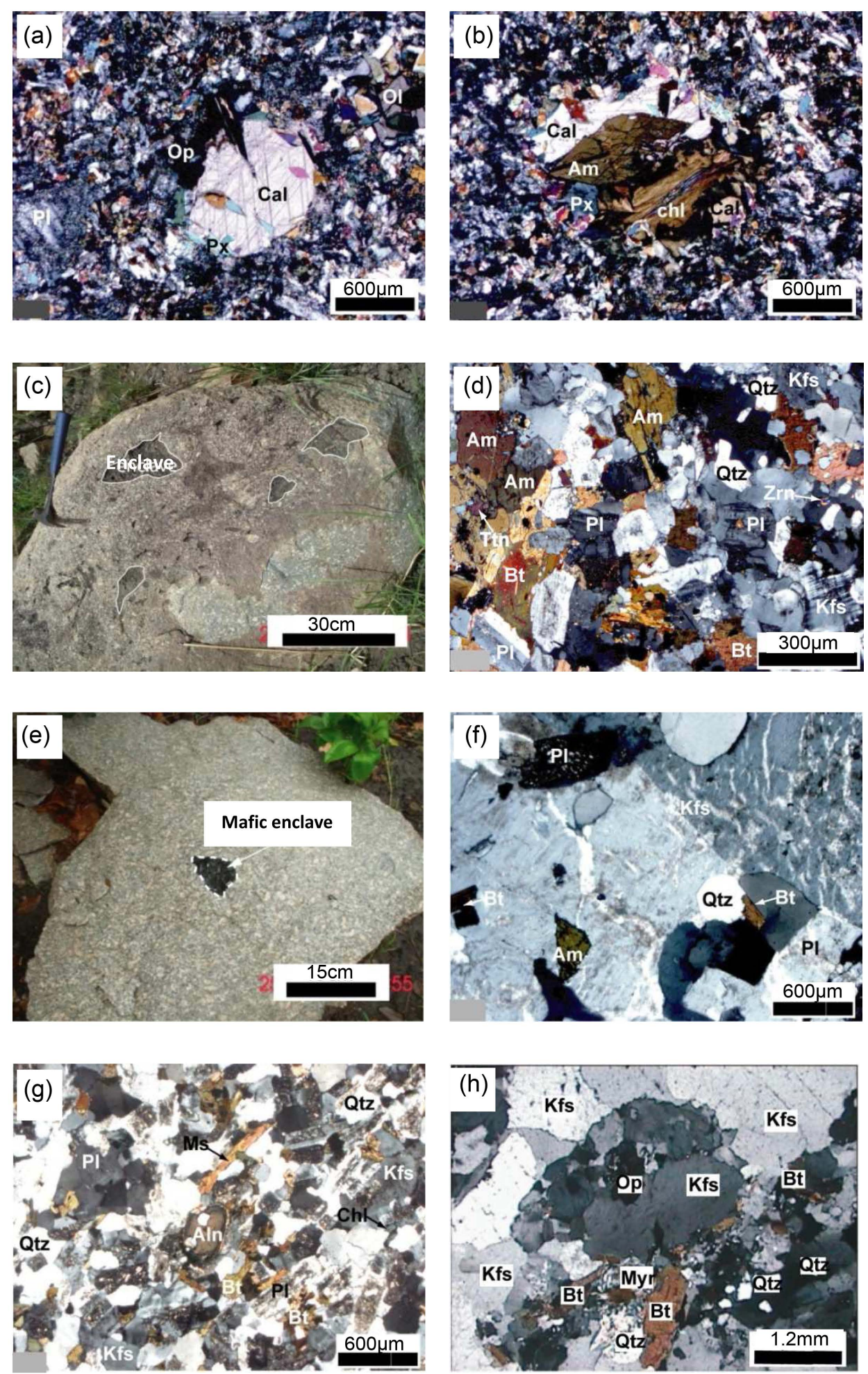

Figure 4. Field photographs (c) (e) and microphotographs (a) (b) (d) (f) (g) (h) showing Field relationships and texture. (a) \& (b) porphyritic texture of gabbro; (c) granodiorite providing angular gabbro enclave. The enclaves are mor or less lined parallel to the foliation; (d) porphyritic texture of granodiorite; (e) coarse grained amphibole biotite granite, showing angular gabbro enclave; (f) porphyritic texture in amphibole biotite granite; (g) oriented texture of fine grained biotite granite; (h) porphyritic texture of coarse grained biotite granite. 
The rock has a granular porphyroid texture (Figure 4(d)) and mainly composed of quartz, plagioclase, alkaline feldspars, biotite, and amphibole.

Quartz is xenomorphic and appears as small crystals $(\leq 50 \mu \mathrm{m})$ interspersed in the rock. Plagioclase exists as automorphic to sub-automorphic crystals, sometimes with zircon, amphibole inclusions and biotite occurrence. Alkaline feldspar is represented by orthoclase and microcline. It is found as sub-euhedral to xenomorphic crystal generally altered. Biotite occurs in anhedral flakes occupying interstices between plagioclase crystals. The amphibole is either a green or a brown hornblende with sub-automorphic crystals form. It is generally twinned and show inclusion of opaque minerals. Amphibole usually crystallizes nearby or between the feldspar crystals and shows the development of titanite. The accessories minerals include titanite and oxides.

2) Amphibole-Biotite granites

Amphibole-biotite granites are widespread (60\% of plutonic rocks) in the massif. They outcrop in blocks, slabs or balls and are light gray in color. Two facies are distinguished: a fine-grain facies that appear as a rounded enclave in another coarse-grain facies. This latter also presents melanocratic angular enclaves that would be gabbroic (Figure 4(e)). The microscopic petrographic study was performed only on the coarse grain facies. At the microscope scale, the rock has a granular porphyroid texture (Figure 4(f)) and constituted of alkaline feldspars in a fine grain matrix made up of small crystals of amphibole, biotite, plagioclase and quartz.

The amphibole is a green hornblende. It appears as anhedral crystals scattered in the rock and usually as inclusions in alkaline feldspars. Alkaline feldspars are represented here by phenocrysts of orthoclase $(>3600 \mu \mathrm{m})$ and small crystals of microcline $(<400 \mu \mathrm{m})$. Orthoclase appears as automorphic crystals and shows the development of lamellar perthites. It also contains amphibole, biotite, quartz, and plagioclase inclusions. Quartz appears either as large anhedral crystals with blunt edges, or as small recrystallized crystals interstitial between plagioclase crystals or filling the feldspars fractures. Plagioclase is sub-automorphic and has borders more or less transformed into a secondary muscovite (sericite). Some crystals have fractures filled by feldspars. Figures of Myrmekites also develop at the level of alkaline feldspars-plagioclase contact. Biotite occurs as sub-automorphic chloritized rims flakes with inclusions of euhedral zircon. Epidote, allanite and chlorite are secondary minerals issued from the transformation of plagioclases and biotite. Accessories minerals include zircon, apatite and oxides.

3) Biotite granites

Biotite granites generally outcrop in the form of slabs behind Yougout village, or in blocks at the WNW end of the massif. Two facies are distinguished: 1) a pink facies coarse-grain (Figure 4(h)); 2) and a light gray facies made of fine grains with an oriented structure underlined by the alignment of biotite (Figure 4(g)).

a) Fine-grain biotite granites

Under the microscope, the rock has an oriented granular texture (Figure 4(g)) and is mainly constituted of quartz, alkali feldspar, plagioclase, biotite and few muscovites.

Quartz is in the form of cracked anhedral crystals of small size $(<100 \mu \mathrm{m})$ as compared to feldspars which occupy the interstitial position. Alkaline feldspars are represented by orthoclase and microcline. They appear as sub-euhedral to anhedral crystal often perthitic, more or less altered and cracked. Plagioclase is in the form of interstitial rims between crystals of alkaline feldspars (orthoclase and microcline) and present alteration undergone by sericite, epidote and chlorite. Biotite is as small anhedral and elongated flakes highlighting the rock fabric. It is sometimes interstitial between feldspars and occasionally contains opaque mineral inclusions. Muscovite occurs in small anhedral elongated flakes. It is frequently in contact with quartz and plagioclase. Secondary minerals are represented by chlorite, sericite and epidote. Accessories minerals include zircon, oxides, titanite and Allanite.

b) Porphyritic biotite granites

Under the microscope, the rock presents a granular porphyroid texture (Figure 4(h)) with phenocrysts of perthitic alkaline feldspars associated to small crystals of quartz, plagioclase and biotite. Quartz is either in the form of cracked anhedral crystals or polycrystalline aggregates of small size and in interstitial position between feldspars or coils around them. Alkaline feldspars are represented by orthoclase and microcline. They are sub-euhedral to anhedral more or less altered and cracked. The large crystals are quite perthitic and the exsolutions are as venules or strips. Plagioclase occurs as tracks smaller in relation to alkaline feldspars. Between alkaline feldspars and plagioclase crystals, quartz vermicules corresponding to myrmekites can be observed. Their alteration yields damourites which is a mixture of epidote, sericite and calcite. Biotite is present as interstitial flakes between feldspars. It is at times transformed into chlorite and sometimes contains zircon and oxides in- 
clusion. Secondary minerals are represented by chlorite, damourite, epidote, sericite and myrmekites crystallizing according to the primary phases. Accessories minerals include zircon, oxides, apatite, allanite and titanite.

\subsection{Geochemistry}

\subsubsection{Major Elements Distribution}

Granitic rocks contain elements in the following range: $\mathrm{SiO}_{2}$ from $64.32 \mathrm{wt} \%$ to $74.82 \mathrm{w} \%, \mathrm{TiO}_{2}$ from $0.21 \mathrm{wt} \%$ to $1.11 \mathrm{w} \% ; \mathrm{Fe}_{2} \mathrm{O}_{3}$ from $1.58 \mathrm{wt} \%$ to $7.17 \mathrm{w} \%$; $\mathrm{MgO}$ from $0.24 \mathrm{wt} \%$ to $1.39 \mathrm{w} \% ; \mathrm{Al}_{2} \mathrm{O}_{3}$ from $13.03 \mathrm{wt} \%$ to 14.41 wt\%; $\mathrm{CaO}$ from $0.98 \mathrm{wt} \%$ to $2.91 \mathrm{wt} \%$ and the ratio $\mathrm{Na}_{2} \mathrm{O} / \mathrm{K}_{2} \mathrm{O}$ from $0.57 \mathrm{wt} \%$ to $0.72 \mathrm{w} \%$. In the classification diagram $\left(\mathrm{SiO}_{2} \mathrm{vs} \mathrm{Na}_{2} \mathrm{O}+\mathrm{K}_{2} \mathrm{O}\right)$ [27] adapted to plutonic rocks by [28] (Figure 5(a)), granodiorites and granites

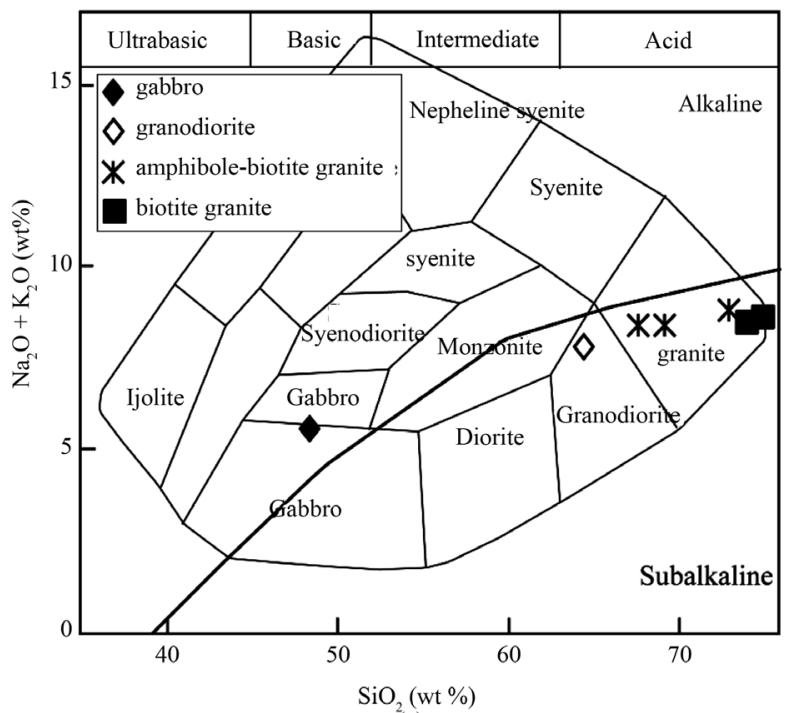

(a)

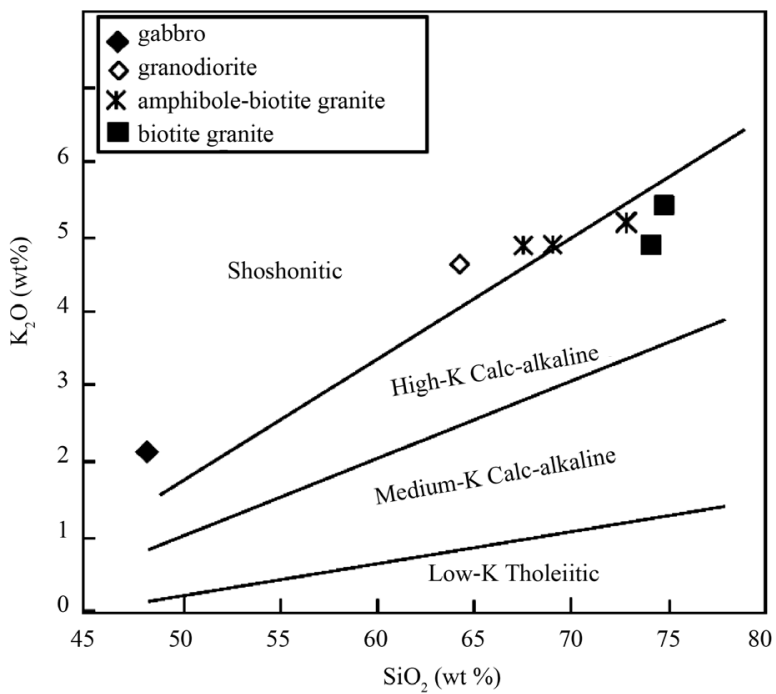

(b)

Figure 5. (a) Plutonic rocks of the Mbip massif in the alkali vs silice diagram. After Cox et al. (1979), adapted to plutonic rocks by Wilson, (1989). The thick curve limit the alkali and sub-alkaline fields; (b) $\mathrm{K}_{2} \mathrm{O}$ vs $\mathrm{SiO}_{2}$ diagram showing shoshonitic to high-K calc-alkaline affinity of the Mbip massif plutonic rock. The limit between calco-alkaline and shoshonitic series is after Le Maître et al. (1989) and Rickwood, (1989). 
have a purely acidic nature and stand in the sub-alkaline series. According to the limits defined by [29] and [30] in the $\mathrm{K}_{2} \mathrm{O}$ vs $\mathrm{SiO}_{2}$ diagram (Figure 5(b)), granodiorites, amphibole-biotite granite and biotite granites display a strongly potassic character. The samples overlap the calc-alkaline and shoshonitic fields. In detail, the granodiorites and amphibole-biotite granites belong to the shoshonitic series while biotite granites are strongly potassic calc-alkaline. Gabbro has percentages of $\mathrm{SiO}_{2}=48.35$ wt $\% ; \mathrm{Fe}_{2} \mathrm{O}_{3}=11.39$ wt\%; $\mathrm{MgO}=6.74$ wt\%; $\mathrm{MgO \#}=$ 49.91; $\mathrm{Al}_{2} \mathrm{O}_{3}=15.11 \mathrm{wt} \%$; $\mathrm{CaO}=7.89 \mathrm{wt} \%$ and the ratio $\mathrm{Na}_{2} \mathrm{O} / \mathrm{K}_{2} \mathrm{O}=1.57$. It is mainly positioned in the alkaline field (Figure 4(a)) and shows a basic nature more than all granitic rocks.

The $\mathrm{SiO}_{2}$ vs oxides diagrams, Harker type, show an almost linear and continuous distribution of points representing different petrographic facies of the Mbip massif (Figure 6). This distribution set good negative correlations between $\mathrm{SiO}_{2}$ and other oxides $\left(\mathrm{Al}_{2} \mathrm{O}_{3}, \mathrm{Fe}_{2} \mathrm{O}_{3}, \mathrm{CaO}, \mathrm{TiO}_{2}, \mathrm{MgO}\right.$, and $\left.\mathrm{P}_{2} \mathrm{O}_{5}\right)$. Their contents decreases with increasing index of differentiation expressed here by silica. Biotite granites show a continuity of composition with other plutonic rocks of the Mbip massif and are the most differentiated facies of the entire pluton. According to [31]-[34], this nearly linear distribution implies the involvement of fractional crystallization processes or magma mixing between a basic magma and acid pole.
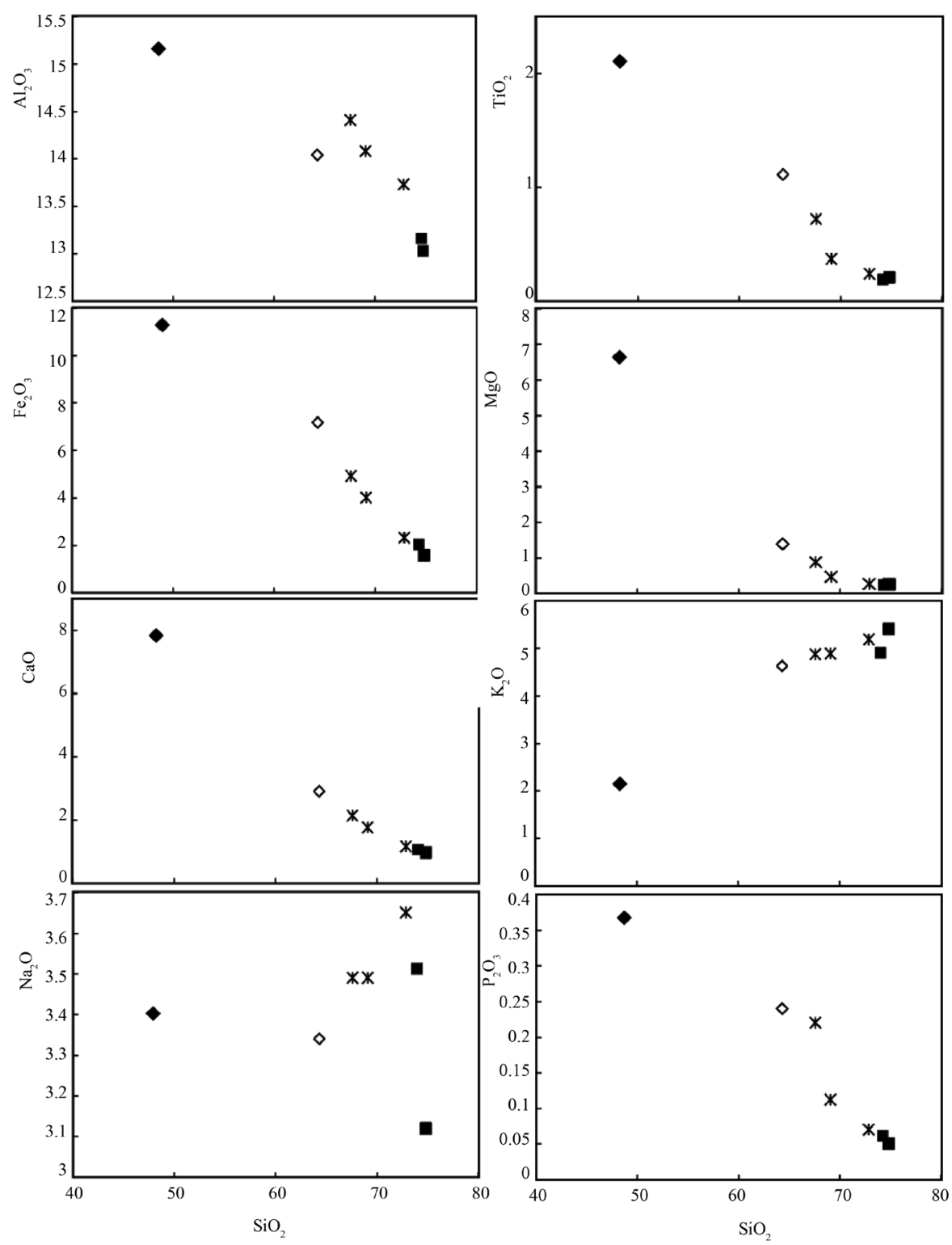

Figure 6. Distribution of the studied plutonic facies in the Harker diagram (oxides vs $\mathrm{SiO}_{2}$ ). 


\subsubsection{Trace Elements Distribution}

Granitic rocks are marked by spectra characterized by an enrichment in light rare earth elements (LREEs) and depletion in heavy rare earth elements (HREEs) (Figure $7(\mathrm{a})$ ). This is expressed by the ratios $(\mathrm{La} / \mathrm{Lu})_{\mathrm{N}}$, $(\mathrm{La} / \mathrm{Yb})_{\mathrm{N}}$ and $(\mathrm{Ce} / \mathrm{Yb})_{\mathrm{N}}$ whose values range respectively between 13.27 to $45.04 ; 13.31$ to 47.84 and from 10.74 to 35.48. They have a fractionated spectrum showing a pronounced negative anomaly in Europium (Eu) when samples are normalized with respect to the primitive mantle of [35]. This anomaly, characteristic of plagioclase fractionation is revealed by the ratio $\mathrm{Eu} / \mathrm{Eu}^{*}$ whose values are respectively 0.54 for granodiorites, between 0.31 and 0.48 for amphibole-biotite granites and between 0.37 and 0.42 for biotite granites. The primitive mantle normalized trace element spidergram of granitic rocks (Figure 7(b)) reveal a strong enrichment in more incompatible elements (Cs, Ba, Rb, Th, U, K) over less incompatible elements (Ti, Y, Yb, Lu) with significant negative anomalies for $\mathrm{Ba}, \mathrm{Nb}, \mathrm{Ta}, \mathrm{Sr}, \mathrm{P}, \mathrm{Ti}$, and positive for $\mathrm{Rb}$, Th, $\mathrm{U}$. These two indications are characteristics of the

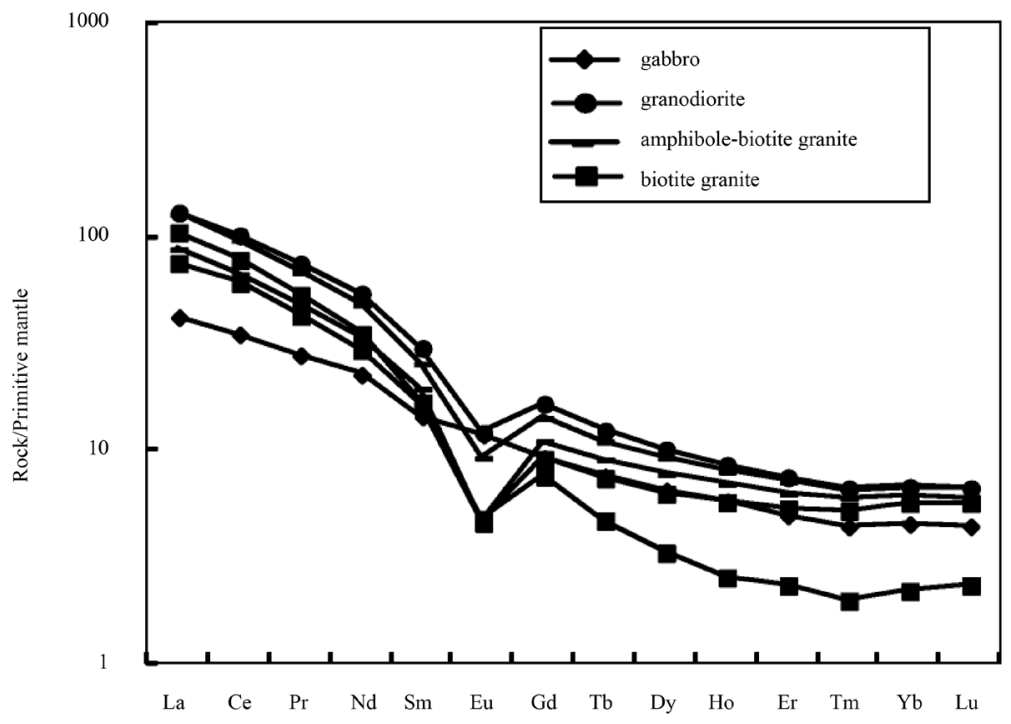

(a)

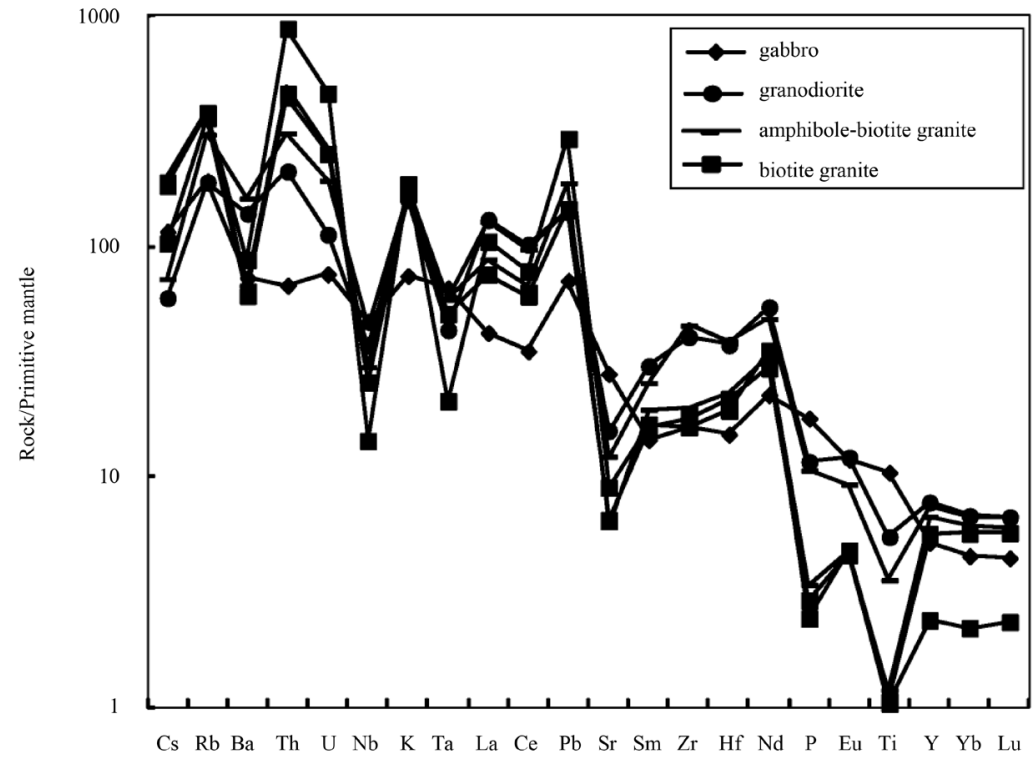

(b)

Figure 7. Primitive-mantle-normalized REE patterns (a) and primitive-mantle-normalized trace element spidergrams (b) for the plutonic rocks examined in the Mbip massif. Primitive-mantle values are from Mcdonough and Sun, (1995). 
orogenic zone magmas [36] [37]. The Nb and Ta negative anomalies are observed in granitic rocks but they are most expressed in biotite granites which support their more differentiated character.

The gabbro spectrum shows an enrichment in light rare earth elements (LREEs) and depletion in heavy rare earth elements (HREEs) (Figure 7(a)) with a ratio $(\mathrm{La} / \mathrm{Yb})_{\mathrm{N}}=9.33$. It has a flat profile and show no negative anomaly in $\mathrm{Eu}\left(\mathrm{Eu} / \mathrm{Eu}^{*}=1.03\right)$. The gabbro spiderdiagram (Figure 7(b)) displays an enrichment in more incompatible elements (Cs, Ba, Rb, Th, U, K) compared to the less incompatible (Ti, Y, Yb, Lu) with an important negative anomaly in $\mathrm{Nb}$ and Ce suggesting crustal contamination. The negative anomalies in $\mathrm{Nb}$ and/or Ta are generally observed in the plutonic rocks of the sub-alkaline series as those studied in the Central Morocco [38]. Based on this distinction, we can consider gabbro as belonging to the sub-alkaline series despite its position in the range of alkaline rocks in the Figure 4(a).

\section{Discussion}

\subsection{Petrogenetic Implication}

The granitic rocks of the Mbip massif are sub-alkaline $\left(\mathrm{Na}_{2} \mathrm{O}+\mathrm{K}_{2} \mathrm{O}<10 \mathrm{wt} \%\right.$ and $\left.\mathrm{Si}_{2} \mathrm{O}>64 \mathrm{wt} \%\right)$ and belong to both shoshonitic and calc-alkaline series (Figure 5). In Figure 5(a), gabbro is rather alkaline; however, based on the negative anomaly in $\mathrm{Nb}$ (Figure 7(b)), we can consider it as belonging to the sub-alkaline series. The studied granitoids are orogenic, and strongly potassic. The variation diagrams for major elements of the studied igneous rocks indicate a magmatic differentiation by fractional crystallization. Indeed, one notices a progressive enrichment in silica and a decrease in $\mathrm{Al}_{2} \mathrm{O}_{3}, \mathrm{Fe}_{2} \mathrm{O}_{3}, \mathrm{CaO}, \mathrm{TiO}_{2}, \mathrm{MgO}$ and $\mathrm{P}_{2} \mathrm{O}_{5}$. These variations appear to reflect a petrographic and chemical continuum from gabbros to biotite granites. However, field observations indicate that the outcrop area of the granitic rocks are much larger compared to those of gabbro, suggesting that we can exclude the possibility that the granitoids are generated from fractional crystallization of mafic magma. Harker diagram (oxide vs $\mathrm{SiO}_{2}$, Figure 6), and classification diagram $\left(\mathrm{Na}_{2} \mathrm{O}+\mathrm{K}_{2} \mathrm{O}\right.$ vs $\mathrm{SiO}_{2}$, Figure 5(a)) show a clear compositional gap between the gabbro and granitic rocks on one hand and the closeness between granitic rocks on the other hand. Also, granitic rocks are more enriched in light rare earth elements (LREEs) compared to gabbro. This led us to suggest that the granitoids were not further established due to the evolution of a mafic magma. In summary, we conclude that the granitic rocks and gabbros have independent origins, and we can suggest the possibility of mixing between granitic and mafic magmas.

Concerning the granitic rocks, the compositional evolution from the granodiorite to the biotite granite (Figure 5(a)) and the content variation of major elements (progressive enrichment in silica and a decrease in $\mathrm{Al}_{2} \mathrm{O}_{3}$, $\mathrm{Fe}_{2} \mathrm{O}_{3}, \mathrm{CaO}, \mathrm{TiO}_{2}, \mathrm{MgO}$ and $\mathrm{P}_{2} \mathrm{O}_{5}$; Figure 6) raise the possibility of fractional crystallization related to the fractionation of mineral phases observed in these rocks. Graphically, the fractionations of plagioclase (decreasing of $\mathrm{CaO}$ contents), apatite (decreasing of $\mathrm{P}_{2} \mathrm{O}_{5}$ contents), magnetite and ilmenite (decreasing of $\mathrm{TiO}_{2}, \mathrm{Fe}_{2} \mathrm{O}_{3}$ contents) in granitic rocks are discernible. Figure 7(a) shows that REE spectrums of granodiorites, amphibole-biotite granites, and biotite granites are strongly fractionated and characterized by a significant negative anomaly in Eu, showing a differentiation controlled by the fractionation of plagioclase feldspars. Primitive mantle normalized trace element spidergrams (Figure 7(b)) for granitic rocks show negative anomalies in Ba, Ti, P, Sr and are respectively related to the crystallization of biotite, opaque minerals such as Ti-magnetite, apatite, plagioclase feldspars.

Gabbro shows a flat spectrum with an absence of Eu negative anomaly. The lack of Eu negative anomaly in the gabbro despite the presence of plagioclase would be due to the presence of water molecules in the liquid magma attested by the presence of hydrated minerals such as amphibole. Indeed, the presence of this water makes the oxidizing environment and prevents $\mathrm{Eu}^{2+}$ binding in the plagioclase.

About the source, gabbro has low contents of $\mathrm{SiO}_{2}, \mathrm{Na}_{2} \mathrm{O}, \mathrm{K}_{2} \mathrm{O}$; high $\mathrm{MgO}, \mathrm{TiO}_{2}, \mathrm{Fe}_{2} \mathrm{O}_{3}, \mathrm{CaO}$ as well as MgO\# (49.91). These contents suggest that it does not represent primary magmas. These characteristics denote that gabbro have a mantle origin. In the contrary, granitic rocks show enrichment in most incompatible elements as well as significant positive anomalies in $\mathrm{Rb}$, Th, $\mathrm{U}$, and negative in $\mathrm{Sr}, \mathrm{P}, \mathrm{Ti}, \mathrm{Nb}$, Ta reflecting the crustal souce in their genesis [37] [39]. Furthermore, the presence of hydrated minerals such as amphibole in some granitic facies suggests a mantle contribution.

\subsection{Tectonic Setting}

In the discriminating diagrams $\mathrm{Ta}$ vs. $\mathrm{Yb}$ and $\mathrm{Rb}$ vs. $(\mathrm{Y}+\mathrm{Nb})$ of [40], most of the granitic rocks samples stand 
in the field of volcanic arc granitoids (Figure 8(a) and Figure 8(b)). In Figure 8(a), two samples of amphibolebiotite granite and one of biotite granites are at the transition position between the syn-collisional and volcanic arc granitoids. In the $\mathrm{Zr}$ vs. (Nb/Zr) diagram of [41], most of the samples fall in the field of collision zones magmatism (Figure 8(c)). These features, combined with their shoshonitic to calc-alkaline strongly potassic character and the presence of pronounced negative anomalies in $\mathrm{Nb}$, $\mathrm{Ta}$, Ti are compatible with subduction geodynamic environment in which the crust was formed originally. But these chemical features are often retained during crustal reprocessing and can also be found in collisionnal-type granitoids [40]. Likewise, shoshonitic to calc-alkaline high potassic affinity are general characteristics of syn- to post-collisionnal granitoids in the continental collision context [42] [43]. Relying on the petrography of main rock types of the massif (granites and granodiorites), their mineralogical composition and the associated mafic rocks (gabbro), the studied granitic rocks either meet with those of ACG type (Ca-amphibole rich calc-alkaline granitoids) or KCG type (K-rich and K-feldspar porphyritic calc-alkaline granitoids) of [39]. Nevertheless, basing on their low calcium percentage $(0.98 \mathrm{wt} \%-2.9 \mathrm{wt} \%)$ and high potassium content (4.63 wt\% - $5.41 \mathrm{wt} \%)$, they stretch more towards KCG type. The KCG types are commonly considered as postorogenic rocks [44] and are identified in the geodynamic zones of continental collision but, largely abundant in transitional regimes [39]. Geochemical characteristics of the studied granitoids are also comparable to those of many syn- to late-tectonic Pan-African granitoids studied

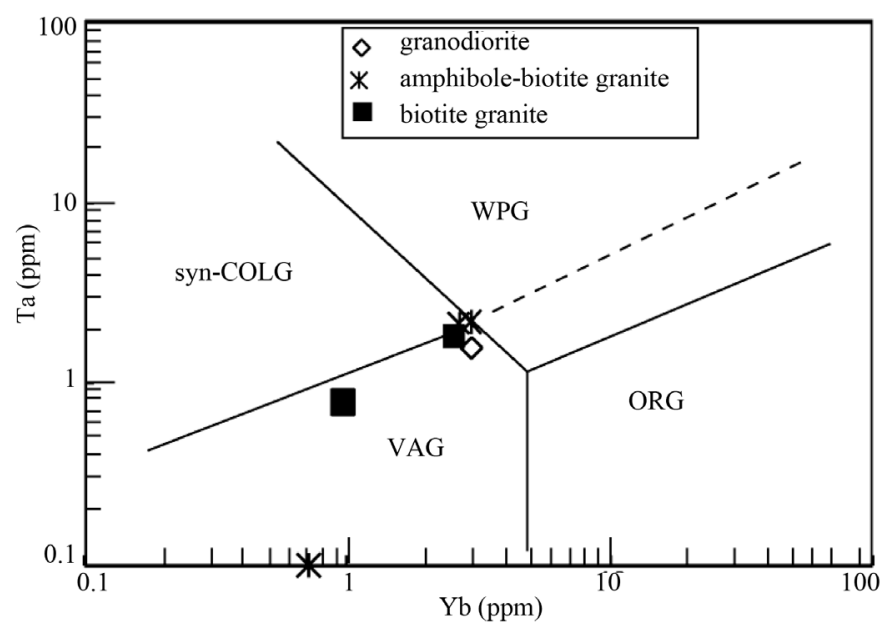

(a)

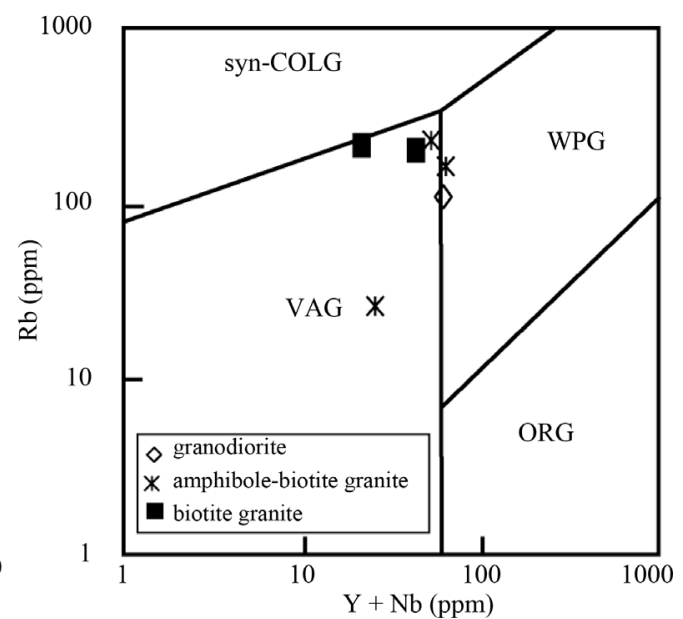

(b)

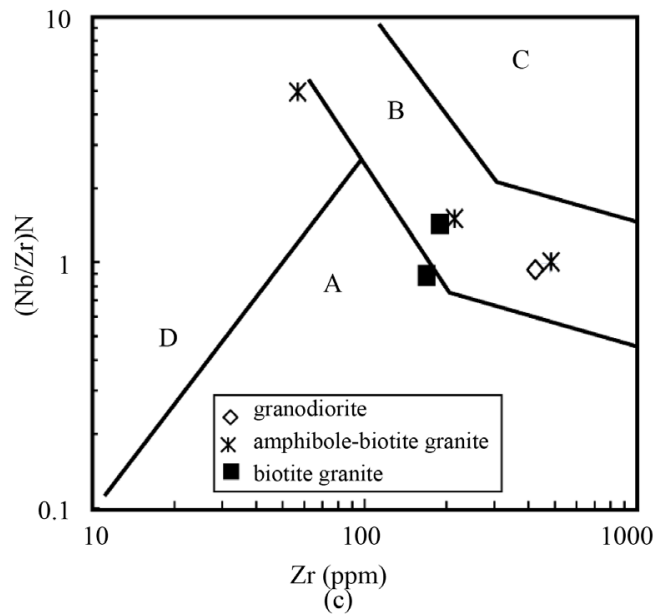

Figure 8. Tectonic discrimination diagram for the granitic rocks of the Mbip massif. Ta vs $\mathrm{Yb}(\mathrm{a})$ and $\mathrm{Rb}$ vs (Y $+\mathrm{Nb})(\mathrm{b})$ with discriminative field after and Pearce et al. (1984): WPG = within plate granites; VAG = volcanic arc granites; syn-COLG = syn-collisionnal granites; ORG: oceanic ridge granite; (c) Zr vs (Nb/Zr)N diagram of Thiéblemont and Tegyey, (1994) for the granitoids of the Mbip massif. A = subduction-zone magmatic rocks; $\mathrm{B}=$ collision zone rocks; $\mathrm{C}=$ alkaline intra-plate zone rocks. Normalization to primitive mantle values from McDonough and Sun (1995). 
in the north [19] [45] and West Cameroon [46].

\section{Summary and Conclusion}

Petrographic and geochemical data obtained on the Mbip massif in Tcholliré region reveal abundan sub-alkaline granitic rocks. These granitoids are associated to mafic rocks represented by gabbros, which outcrop often as angular enclave. Granitic rocks are made of granodiorites, amphibole-biotite granite and biotite granites. Geochemical data indicates that these granitoids are shoshonitic to strongly potassic calc-alkaline and probably derived from a magmatic differentiation resulting from the melting of the continental crust base. On the contrary, gabbro displays geochemical characteristics indicating mantle origin. Petrographic and geochemical data show that the granitic Mbip massif is late- to post-collisional and emplaced at the end of continental collision.

\section{Acknowledgements}

The first author thanks greatly the "Service de Coopération et d'Action Culturelle de l'Ambassade de France au Cameroon (Yaoundé)" for scholarship attributed. The vice-chancellor of the Yaoundé I University is thanked for absence authorizations and Campus France for organizing visits in France (Nancy and Toulouse). This work benefited from the financial support of the AUF (Project no 51011SU201) and from the NEEDS program of the CNRS-INSU.

\section{References}

[1] Toteu, S.F., Van Schmus, W.R., Penaye, J. and Michard, A. (2001) New U-Pb and Sm-Nd Data from North-Central Cameroon and Its Bearing on Pre-Pan African History of Central AFRICA. Precambrian Research, 108, 45-73. http://dx.doi.org/10.1016/S0301-9268(00)00149-2

[2] Toteu, S.F., Penaye, J. and Poudjom Djomani, Y. (2004) Geodynamic Evolution of the Pan-African Belt in Central Africa with Special Reference to Cameroon. Canadian Journal of Earth Sciences, 41, 73-85. http://dx.doi.org/10.1139/e03-079

[3] Poidevin, J.L. (1983) La tectonique Pan-Africaine à la bordure Nord du craton congolais: l’orogénèse des Oubanguides. 12th Colloque on te African Geology, Musée Royal de l'Afrique Central, Tervuren, Abstract, 75.

[4] Nzenti, J.P., Barbey, P., Macaudière, J. and Soba, D. (1988) Origin and Evolution of the Late Precambrian High-Grade Yaoundé Gneisses (Cameroon). Precambrian Research, 38, 91-109. http://dx.doi.org/10.1016/0301-9268(88)90086-1

[5] Ngako, V., Jegouzo, P. and Nzenti, J.P. (1992) Champ de raccourcissement et de cratonisation du Nord Cameroun du Protérozoïque Supérieur au Protérozoïque Moyen. Comptes Rendu de l'Académie des Sciences de Paris, 315, 371-377.

[6] Ngako, V., Affaton, P., Nnange, J.M. and Njanko, Th. (2003) Pan-African Tectonic Evolution in Central and Southern Cameroon: Transpression and Transtension during Sinistral Shear Movements. Journal African Earth Sciences, 36, 207-214. http://dx.doi.org/10.1016/s0899-5362(03)00023-x

[7] Theunissen, K., Lenoir, J.L., Liegeois, J.P., Delvaux, D. and Murma, A. (1992) Empreinte Pan-Africaine majeure dans la chaîne ubendienne de Tanzanie Sud-occidentale: géochronologie U-Pb sur zircon et contexte structural. Comptes Rendu de l'Académie des Sciences de Paris, 314, 1355-1362.

[8] Castaing, C., Feybesse, J.L., Thiéblemont, D., Triboulet, C. and Chèvremont, P. (1994) Palaeogeographical Reconstructions of the Pan-African/Brasiliano Orogen: Closure of an Oceanic Domain or Intracontinental Convergence between Major Blocks. Precambrian Research, 67, 327-344. http://dx.doi.org/10.1016/0301-9268(94)90095-7

[9] Abdelsalam, M.C., Liegeois, J.P. and Stren, R.J. (2002) Review: the Saharan Metacraton. Journal of African Earth Sciences, 34, 119-136. http://dx.doi.org/10.1016/S0899-5362(02)00013-1

[10] Leroy, B. and Cirrotteau, A. (1962) Carte géologique de reconnaissance de la République Fédérale du Cameroun feuille $\mathrm{N}^{\circ}$ : NC 33 SO E53. Société Nouvelle de Cartographie-Lith, Paris.

[11] Pinna, P., Calvez, J.Y., Abessolo, A., Angel, J.M., Mekoulou, T., Mananga, G. and Vernhet, Y. (1994) Neoproterozoic Events in the Tcholliré Area: Pan-African Crustal Growth and Geodynamics in Central-Northern Cameroon (Adamawa and North Provinces). Journal of African Earth Sciences, 18, 347-353. http://dx.doi.org/10.1016/0899-5362(94)90074-4

[12] Ganwa, A.A., Wolfgand, F., Wolfgand, S., Ekodeck, E.G., Cosmas, K.S. and Ngako, V. (2008) Archaean Inheritances in the Pyroxene-Amphibole-Bearing Gneiss of the Méiganga Area (Central North Cameroon): Geochemical and 207Pb/206Pb Age Imprints. Comptes Rendus Geoscience, 340, 211-222. http://dx.doi.org/10.1016/j.crte.2007.12.009

[13] Bouyo, H.M., Toteu, S.F., Deloule, E., Penaye, J. and Van Schmus, W.R. (2009) U-Pb and Sm-Nd Dating of High- 
Pressure Granulites from Tcholliré and Banyo Regions: Evidence for a Pan-African Granulite Facies Metamorphism in North-Central Cameroon. Journal of African Earth Sciences, 54, 144-154. http://dx.doi.org/10.1016/j.jafrearsci.2009.03.013

[14] Soba, D., Michard, A., Toteu, S.F., Norman, D.I., Penaye, J., Ngako, V., Nzenti, J.P. and Dautel, D. (1991) Données géochronologiques nouvelles (Rb-Sr, U-Pb et Sm-Nd) sur la zone mobile panafricaine de l'Est Cameroun: Âge protérozoique supérieur dela série de Lom. Comptes rendus de l'Académie des sciences de Paris, 315, 1453-1458.

[15] Toteu, S.F., Penaye, J., Deloule, E., Van Schmus, W.R. and Tchameni, R. (2006) Diachronous Evolution of VolcanoSedimentary Basins North of the Congo Craton: Insights from U-Pb Ion Microprobe Dating of Zircons from the Poli, Lom and Yaoundé Groups (Cameroon). Journal of African Earth Sciences, 44, 428-442. http://dx.doi.org/10.1016/j.jafrearsci.2005.11.011

[16] Njanko, T., Nédélec, A. and Affaton, P. (2006) Synkinematic High-K Calc-Alkaline Plutons Associated with the PanAfrican Central Cameroon Shear Zone (W-Tibati Area): Petrology and Geodynamic Significance. Journal of African Earth Sciences, 44, 494-510. http://dx.doi.org/10.1016/j.jafrearsci.2005.11.016

[17] Nzenti, J.P., Kapajika, B., Wörner, G. and Lubala, T.R. (2006) Synkinematic Emplacement of Granitoids in a PanAfrican Shear Zone in Central Cameroon. Journal of African Earth Sciences, 45, 74-86. http://dx.doi.org/10.1016/j.jafrearsci.2006.01.005

[18] Toteu, S.F., Van Schmus, W.R., Penaye, J. and Nyobé, J.B. (1994) U-Pb and Sm-Nd Evidence for Eburnean and PanAfrican High-Grade Metamorphism in Cratonic Rocks of Southern Cameroon. Precambrian Research, 67, 321-347. http://dx.doi.org/10.1016/0301-9268(94)90014-0

[19] Tchameni, R., Pouclet, A., Penaye, J., Ganwa, A.A. and Toteu, S.F. (2006) Petrography and Geochemistry of the Ngaoundéré Pan-African Granitoïds in Central Nord Cameroon: Implication for Their Sources and Geological Setting. Journal of African Earth Sciences, 44, 511-529. http://dx.doi.org/10.1016/j.jafrearsci.2005.11.017

[20] Tagne-Kamga, G. (2003) Petrogenesis of the Neoproterozoic Ngondo Plutonic Complex (Cameroon, West Central Africa): A Case of Late-Collisional Ferro-Potassic Magmatism. Journal of African Earth Sciences, 36, 49-171. http://dx.doi.org/10.1016/S0899-5362(03)00043-5

[21] Ngako, V., Affaton, P., Nnange, J.M. and Njanko, T. (2003) Pan-African Tectonic Evolution in Central and Southern Cameroon: Transpression and Transtension during Sinistral Shear Movements. Journal of African Earth Sciences, 36, 207-214. http://dx.doi.org/10.1016/S0899-5362(03)00023-X

[22] Daouda, D., Bouchez, J.L., Paquette, J.L. and Tchameni, R. (2013) The Pan-African Quartz-Syenite of Guider (North-Cameroon): Magnetic Fabric and U-Pb Dating of the Late-Orogenic Emplacement. Precambrian Research, 236, 132-144. http://dx.doi.org/10.1016/j.precamres.2013.07.008

[23] Ferre, E., Deleris, J., Bouchez, J.L., Lar, A.U. and Peucat, J.J. (1996) The Pan-African Reactivation of Eburnean and Archaean Provinces in Nigeria: Structural and Isotopic Data. Journal of Geological Society of London, 153, 719-728. http://dx.doi.org/10.1144/gsjgs.153.5.0719

[24] Noël, Y., Maurizot, P. and Roubrichou, P. (1986) Inventaire minier de Centre-Nord Cameroun: Phase préliminaire. Open-File Report 86 CMR 078, Bureau de Recherches Géologiques et Minières, France.

[25] Pinna, P., Abessolo, A., Angel, J.M., Mananga, G., Mekoulou, T.M., Vernhet, Y. and Viallefond, L. (1988) Inventaire minier du Centre-Nord Cameroun (2ème phase). Open-File Report 87 CMR 207, Bureau de Recherches Géologiques et Minières, France.

[26] Pinna, P., Edimo, A., Jézéquel, J., Tchountchoui, D. and Ebotayuk-Ebop, M. (1989) Inventaire minier du Centre-Nord Cameroun (Troisième Phase). Open-File Report 88 CMR 168, Bureau de Recherches Géologiques et Minières, France.

[27] Cox, K.G., Bell, J.D. and Pankhurst, R.J. (1979) The Interpretation of Igneous Rocks. George, Allen \& Unwin, London. http://dx.doi.org/10.1007/978-94-017-3373-1

[28] Wilson, M. (1989) Igneous Petrogenesis. Unwin Hyman, London. http://dx.doi.org/10.1007/978-1-4020-6788-4

[29] Le Maître (1989) A Classification of Igneous Rocks and Glossary of Terms. Blackwell, Oxford.

[30] Rickwood, P.C. (1989) Boundary Lines within Petrologic Diagrams Which Use Oxides of Major and Minor Elements. Lithos, 22, 247-263. http://dx.doi.org/10.1016/0024-4937(89)90028-5

[31] Clemens, J.D. and Wall, V.J. (1981) Origin and Crystallization of Some Peraluminous (S-Type) Granitic Magmas. Canadian Mineralogist, 19, 111-131.

[32] Kouchi, A. and Sunagawa, I. (1985) A Model for Mixing Basaltic and Dacitic Magmas as Deduced from Experimental Data. Contributions to Mineralogy and Petrology, 89, 17-23. http://dx.doi.org/10.1007/BF01177586

[33] Zorpi, M.J., Coulon, C., Orsini, J.B. and Cocirta, C. (1989) Magma Mingling, Zoning and Emplacement in Calc-Alkaline Granitoid Plutons. Tectonophysics, 157, 315-329. http://dx.doi.org/10.1016/0040-1951(89)90147-9 
[34] Orsini, J.B., Cocirta, C. and Zorpi, M.J. (1991) Genesis of Mafic Microgranular Enclaves through Differentiation of Basic Magmas, Mingling and Chemical Exchange with Their Host Granitoid Magmas. In: Didier, J. and Barbarin, B., Eds., Enclaves and Granite Petrology, Developments in Petrology, Volume 13, Elsevier, Amsterdam, 445-463.

[35] McDonough, W.F. and Sun, S.S. (1995) The Composition of the Earth. Chemical Geology, 120, 223-253. http://dx.doi.org/10.1016/0009-2541(94)00140-4

[36] Saunders, A.D., Tarney, J. and Weaver, S.D. (1980) Transverse Geochemical Variations across the Antarctic Peninsula: Implications for the Genesis of Calc-Alkaline Magmas. Earth and Planetary Science Letters, 46, 344-360. http://dx.doi.org/10.1016/0012-821X(80)90050-3

[37] Taylor, S.R. and McLennan, S.M. (1985) The Continental Crust: Its Composition and Evolution. Blackwell, Oxford, $312 \mathrm{p}$.

[38] Haïmeur, J., El Amrani, I.E. and Chabane, A. (2004) Pétrologie des granitoïdes calco-alcalins de Zoër (Maroc Central): Modèle pétrogénétique. Bulletin de l'Institut Scientifique, Rabat, Section Sciences de la Terre, 26, 27-48.

[39] Barbarin, B. (1999) A Review of the Relationships between Granitoid Types, Their Origins and Their Geodynamic Environments. Lithos, 46, 605-626. http://dx.doi.org/10.1016/S0024-4937(98)00085-1

[40] Pearce, J.A., Harris, N.B.W. and Tindle, A.G. (1984) Trace Element Discrimination Diagrams for the Tectonic Interpretation of Granitic Rocks. Journal of Petrology, 25, 956-983. http://dx.doi.org/10.1093/petrology/25.4.956

[41] Thiéblemont, D. and Tegyey, M. (1994) Une discrimination géochimique des Roches différenciées témoin de la diversité d'origine et de situation Tectonique des magmas calco-alcalins. Comptes Rendus de l'Académie Des Sciences, 319, 87-94.

[42] Black, R. and Liégeois, J.P. (1993) Cratons, Mobile Belts, Alkaline Rocks and Continental Lithospheric Mantle: The Pan-African Testimony. Journal of the Geological Society, 150, 89-98. http://dx.doi.org/10.1144/gsjgs.150.1.0088

[43] Liégeois, J.P., Black, R., Navez, J. and Latouche, L. (1994) Early and Late Pan-African Orogenies in the Aïr Assembly of Terranes (Tuareg Shield, Niger). Precambrian Research, 67, 59-88. http://dx.doi.org/10.1016/0301-9268(94)90005-1

[44] Lameyre, J., Autran, A., Barrière, M., Bonin, B., Didier, J., Fluck, P., Fourcade, S., Giraud, P., Jonin, M., Orsini, J.B. and Vivier, G. (1980) Les granitoïdes de France.. In: Autran, A. and Dercourt, J., Eds., Evolutions Géologiques de la France, Vol. 107, Mem. B.R.G.M., 51-97.

[45] Ganwa, A.A., Siebel, W., Frisch, W., Shang, C.K. and Ekodeck, G.E. (2011) Geochemistry and Geochronology of the Méiganga Metadiorite: Implications on the Timing of D2 Deformational Phase in Adamawa Yadé Domain in Cameroon. International Journal of Biological and Chemical Sciences, 5, 1754-1767.

[46] Djouka-Fonkwé, M.L., Schulz, B., Schüssler, U., Tchouankoué, J.P. and Nzolang, C. (2008) Geochemitry of the Bafoussam Pan-African I- and S-Type Granitoids in Western Cameroon. Journal of African Earth Sciences, 50, 148-167. http://dx.doi.org/10.1016/j.jafrearsci.2007.09.015 